\title{
HABITAT KEANEKARAGAMAN HAYATI DAN PUSAT JAJANAN SEBAGAI PEMBANGKIT LISTRIK TENAGA BIOENERGI
}

\author{
Bobby Febrian ${ }^{1)}$, Denny Husin ${ }^{2)}$ \\ 1)Program Studi S1 Arsitektur, Fakultas Teknik, Universitas Tarumanagara, bobbyfebob@gmail.com \\ 2) Program Studi S1 Arsitektur, Fakultas Teknik, Universitas Tarumanagara, denny@ft.untar.ac.id
}

\begin{abstract}
Abstrak
Fenomena Covid-19 membuat manusia merefleksikan kembali hubungannya dengan ekosistem sehingga mempercepat kesadaran ekologis, bahwa ada entitas lain yang harus diperhatikan selain manusia. Antroposentrisme adalah paham bahwa manusia adalah spesies paling berkuasa daripada makhluk lainnya, kegiatan antroposentrisme yang di angkat adalah pembangunan masif kawasan-kawasan bisnis ditengah kota Jakarta. Tujuan proyek ini bertujuan mengevaluasi pembangunan masif dengan menambahkan kebijakan pembangunan yang memperhatikan ruang untuk makhluk selain manusia yaitu hewan dan tumbuhan. Pemikiran seperti ini disebut dengan ecosophy, yang berarti bijak dalam kehidupan ekologis. Secara hipotesa ruang terbuka hijau yang diterapkan pada perancangan dapat dimanfaatkan sebagai habitat makhluk hidup dan dapat dimanfaatkan juga sebagai pembangkit listrik menggunakan proses biogas dan biokatoda. Biogas adalah gas alam yang terproses secara anaerobik atau tanpa oksigen, bahan bakunya berasal dari sisa makanan yang terdapat pada program pusat jajanan dalam bentuk substrat bahan organik. Biokatoda adalah proses penyerapan elektron yang dihasilkan mikroba dari hasil fotosintesis yang menggunakan alat elektroda untuk menyerap elektron. Kedua proses tersebut menghasilan energi yang berasal dari alam atau disebut dengan bioenergi, yang digunakan sebagai pembangkit listrik untuk skala lingkungan. Dengan cara ini didapatkan bahwa proyek ini berfokus kepada perancangan yang bukan hanya berkelanjutan tetapi juga memperbarui lingkungan sekitarnya. Hasil yang di dapat pada proyek ini adalah menghadirkan sebuah bangunan dengan pemahaman ecosophy yang mengedepankan kebijakan ekologis dalam merancang, mempunyai hubungan mutualisme dalam bentuk habitat keanekaragaman hayati yang menyuplai substrat bahan organik untuk dapat dimanfaatkan oleh manusia mendapatkan listrik yang dihasilkan dari bioenergi.
\end{abstract}

\section{Kata kunci: antroposentrisme; bioenergi; biogas; biokatoda; ecosophy.}

\begin{abstract}
The Covid-19 phenomenon makes humans stimulates their relationship with ecosystems, thereby accelerating ecological awareness, that there are other entities must be considered besides humans. Anthropocentrism is the understanding that humans are the most powerful species than other creatures, the discussed one anthropocentrism activity are about the massive development of business areas in the middle of Jakarta. The purpose of this project is to evaluate massive development by adding development policies that pay attention to spaces for creatures other than humans, namely animals and plants. This kind of thinking is called ecosophy, which means wise in ecological living. Hypothetically, the green open space applied to the design can be used as a habitat for living things and can also be used as a power plant using biogas and biocathode processes. Biogas is natural gas that is processed anaerobically or without oxygen, the raw material comes from food scraps contained in the food court program in the form of organic material substrates. Biocathode is the process of absorbing electrons that produced by microbes from photosynthesis process that uses electrodes to absorb electrons. Both processes produce energy that comes from nature or known as bioenergy, which is used to generate electricity on an environmental scale. Therefore, the project focuses on design that is not only sustainable but also regenerating
\end{abstract}


the surrounding environment. The results about the project are to present a building with an ecosophy thinking that puts forward ecological policies in designing, it has a mutualistic relationship in the form of a biodiversity habitat that supplies organic material substrates to be used by humans to obtain electricity generated from bioenergy.

Keywords: anthropocentricism; bioenergy; biogas; biocathode; ecosophy.

\section{PENDAHULUAN}

\section{Latar Belakang}

Pandemi Covid-19 membuat manusia merefleksikan kembali hubungannya dengan ekosistem, terutama di masa lockdown, selain ekonomi secara global turun, polusi dan emisi karbon juga turun sehingga berdampak positif bagi ekosistem. Efek lockdown saat pandemi mempercepat kesadaran ekologis karena terasa langsung oleh manusia perubahannya secara singkat. Hal ini menimbulkan kesadaran bahwa ada entitas lain yang harus dipikirkan selain manusia, sehingga membawa pergeseran menuju paradigma yang non-antroposentris (Bar, 2020).

Jakarta merupakan ibukota sekaligus kota metropolitan dengan kepadatan penduduk 16.704 jiwa/km2, Jakarta dilihat sebagai jantung agenda kapitalis dan antroposentris yang ada di Indonesia, yang dampaknya dapat dilihat dari luar kota Jakarta, seperti kegiatan pabrik produksi, Pembangkit Listrik Tenaga Uap (PLTU) di daeah pesisir, manufaktur material. bahkan hubungan diplomasi dan ekonomi di Jakarta berperan besar dalam terjadinya peristiwa ekosida. Sebagian besar kegiatan tersebut untuk memenuhi kebutuhan di ibukota, yang sehingga menyebabkan ketidakselarasan ekologi secara nasional maupun global (Bilqis, 2020).

Fenomena yang diangkat adalah tentang kekejaman kota Jakarta sebagai perusak keseimbangan ekologis, terutama permasalahan pembangunan masif di Jakarta terkhusus pada kawasan bisnis yang terletak pada garis imajiner segitiga emas Jakarta, yang hanya terfokuskan merancang untuk manusia sepihak. Kita sebagai manusia terbiasa dengan egoisme dalam setiap tindakan kita, hal ini membuat kita tidak memiliki waktu untuk memikirkan makhluk hidup lainnya dan mendekatkan manusia kepada sifat alamiahnya ingin menguasai atas segala sesuatu atau yang disebut dengan antroposentris.

\section{Rumusan Permasalahan}

Permasalahan yang diangkat dari isu ekologi dan antroposentrisme yang berlatar di pusat bisnis Jakarta. Sehingga berdasarkan latar belakang diatas terdapat beberapa rumusan masalah yaitu:

a. Bagaimana menyikapi pandangan antroposentrisme dalam pembangunan yang hanya menguntungkan manusia sepihak.

b. Bagaimana upaya arsitektural dalam menyadarkan manusia akan interdependensinya dengan alam.

c. Apa program yang dapat menjembatani aktivitas manusia dan non-manusia dalam konteks perkantoran.

\section{Tujuan}

Tujuan proyek ini lebih berfokus kepada penyelesaian didalam kawasan bisnis atau perkantoran, sehingga proyek ini dapat memberikan manfaat terhadap skala lingkungan yang diharapkan dapat meningkatkan kesejahteraan ekosistem lingkungannya, berikut beberapa tujuan proyek ini yaitu:

a. Mengevaluasi kebijakan perancangan arsitektural berdasarkan pemikiran ecosophy.

b. Membuat rancangan dengan konsep ekologis, dengan memanfaatkan setiap limbah organik dari makanan dan tumbuhan menjadi energi alam yang bermanfaat untuk seluruh subjek pada Kawasan. 
c. Membuat program yang berperan sebagai perantara antara kebutuhan manusia dan nonmanusia dalam konteks lokal untuk menciptakan interdependensi antar makhluk hidup.

\section{KAJIAN LITERATUR}

\section{Ecosophy}

Kata ecosophy berasal dari kata 'oikos' dan 'sophia', sophy berasal dari istilah Yunani sophia, yaitu kebijaksanaan. Pada dasarnya ecosophy prinsip biospheric egalitarianism atau persamaan hak, bahwa seluruh makhluk hidup adalah anggota yang memiliki martabat yang sama dari suatu keseluruhan yang terkait. Pemikiran tersebut membawa kepada pemahaman nonantroposentrisme (Devall, 1985). Jika dikaitkan dengan arsitektur, konsep ecosophy mengacu kepada perancangan yang lebih hijau seperti (Naboni \& Havinga, 2019):

a. Konsep membaharui, energi terus berputar dan dimanfaatkan untuk kebutuhan makhluk hidup bukan hanya manusia.

b. Minimal penggunaan lahan dan pengubahan eksisting dan kontur tapak.

c. Pengunaan energi dan material dari alam yang bersifat membaharui dan bertumbuh.

d. Mendesain secara holistik untuk kebaikan dan persamaan hak makhluk hidup.

\section{Parameter Ecosophy Untuk Arsitektur}

Untuk mempermudah perancangan, diperlukan perumusan parameter agar tetap dalam cangkupan pembahasan. Parameter diformulakan berdasarkan prinsip ecosophy yang terdapat dalam kajian literatur, berikut diantaranya;

Tabel 1. Parameter Ecosophy

\begin{tabular}{|c|c|c|}
\hline Parameter & Poin Penjelasan & Sumber Buku \\
\hline $\begin{array}{l}\text { Trans- } \\
\text { Corporeal }\end{array}$ & $\begin{array}{l}\text { - Saling terhubung dengan lingkup relasi sosial kepada } \\
\text { keseluruhan makhluk hidup bahkan dengan komunitas } \\
\text { disekitarnya (context) } \\
\text { - Persamaan hak dan status antar makhluk ciptaan } \\
\text { - Menghilangkan kesenjangan status dan relasi sosial antar } \\
\text { manusia }\end{array}$ & $\begin{array}{l}\text { Bodily Nature } \\
\text { (Alaimo, 2010) } \\
\text { Prismatic Ecology } \\
\text { (Cohen, 2013) } \\
\text { (Haenlein, 2016) }\end{array}$ \\
\hline $\begin{array}{l}\text { Non- } \\
\text { Anthroposentris }\end{array}$ & $\begin{array}{l}\text { - Berpikir holistik dalam setiap keputusan dengan } \\
\text { mempertimbangkan setiap makhluk } \\
\text { - Tidak menilai manusia sebagai penguasa dari alam } \\
\text { semesta, melainkan bagian dari alam itu sendiri } \\
\text { - Merancang untuk kebaikan dan kehidupan seluruh } \\
\text { makhluk beserta ekosistemnya } \\
\text { - Memiliki kesadaran akan dampak, tanggung jawab, dan } \\
\text { batasan rancangan atas desakan krisis lingkungan }\end{array}$ & $\begin{array}{l}\text { Deep Ecology } \\
\text { (Devall, 1985) } \\
\text { Prismatic Ecology } \\
\text { (Cohen, 2013) }\end{array}$ \\
\hline $\begin{array}{l}\text { Biomimetic } \\
\text { Principle }\end{array}$ & $\begin{array}{l}\text { - Salah satu pendekatan untuk mengharmonikan struktur } \\
\text { buatan manusia dan lingkungan alam } \\
\text { - Pendekatan logika ekologis untuk membuat sistem dan } \\
\text { Inovasi desain yang terinspirasi oleh alam } \\
\text { - Merubah persepsi dengan melihat alam sebagai bahan } \\
\text { baku, keutamaan, fungsi tambahan, dan estetika daripada } \\
\text { melihatnya sebagai hambatan atau rintangan didalam } \\
\text { tapak. } \\
\text { - Kemampuan beradaptasi dan bertahan dari bermacam } \\
\text { bencana maupun ancaman iklim yang terus berubah }\end{array}$ & $\begin{array}{l}\text { Architecture Follow } \\
\text { Nature } \\
\text { (Mazzoleni, 2013) }\end{array}$ \\
\hline
\end{tabular}




\begin{tabular}{|c|c|c|}
\hline $\begin{array}{l}\text { Regenerative } \\
\text { Design }\end{array}$ & $\begin{array}{l}\text { - Design memiliki dampak yang memperbaharui lingkungan } \\
\text { bukan hanya melestarikan lingkungan } \\
\text { - Memperbaharui keanekaragaman hayati dan nabati } \\
\text { - Minimalisir dampak lingkungan dari bangunan maupun } \\
\text { pembangunan dan efek karbon } \\
\text { - Membangun seminimal mungkin dan maksimalkan } \\
\text { fungsional sehingga meminimalisir dampak dari konstruksi } \\
\text { bangunan }\end{array}$ & $\begin{array}{l}\text { Regenerative } \\
\text { Architecture (Cook, } \\
\text { 2019) }\end{array}$ \\
\hline $\begin{array}{l}\text { Machine } \\
\text { Adaptation }\end{array}$ & $\begin{array}{l}\text { - Mesin dapat berkontribusi dalam penciptaan iklim mikro } \\
\text { yang berdampak pada habitat maupun ekosistem sekitar } \\
\text { - Pemanfaatan teknologi terbaru untuk meningkatkan } \\
\text { kualitas hidup makhluk hidup atau setidaknya lingkup } \\
\text { lingkungan sekitar } \\
\text { - Berfokus kepada teknologi yang minim energi dan } \\
\text { pengunaan material } \\
\text { - Menjunjung prinsip Cradle to Cradle, yang merupakan } \\
\text { pendekatan produk sirkular yang diproduksi ulang terus } \\
\text { menerus sehingga tidak ada limbah dalam prosesnya }\end{array}$ & $\begin{array}{l}\text { Machine Landscape } \\
\text { (Young, 2019), } \\
\text { Grey Ecology } \\
\text { (Broadbent \& Lobet- } \\
\text { Maris, 2015) } \\
\text { Cradle to Cradle } \\
\text { (McDonough \& } \\
\text { Braungart, 2002) }\end{array}$ \\
\hline $\begin{array}{l}\text { Terraforming } \\
\text { Digital }\end{array}$ & $\begin{array}{l}\text { - Minimalisir polusi digital (file yang tidak dipakai) sehingga } \\
\text { tidak memerlukan luasan data center yang terlalu masif } \\
\text { - Memahami energi digital melalui Cloud Terraforming } \\
\text { sehingga terdapat kemungkinan untuk dimanfaatkan bagi } \\
\text { kebaikan seluruh makhluk } \\
\text { - Kemampuan melihat Big Data dalam menentukan taktik } \\
\text { dalam membangun kualitas spasial } \\
\text { - Mentransformasi limbah dan data digital menjadi sumber } \\
\text { energi terbarukan }\end{array}$ & $\begin{array}{l}\text { The Stack (Bratton, } \\
\text { 2015), } \\
\text { Grey Ecology } \\
\text { Grey Ecology } \\
\text { (Broadbent \& Lobet- } \\
\text { Maris, 2015) }\end{array}$ \\
\hline
\end{tabular}

Sumber: Penulis, 2021

\section{Bioenergi}

Bioenergi adalah energi terbarukan yang didapatkan dari sumber biologis, umumnya biomassa. Biomassa adalah bahan organik yang menyimpan energi cahaya matahari dalam bentuk energi kimia. Biomassa sebagai bahan bakar umumnya berupa kayu, limbah industri kayu, jerami, dan hasil pertanian seperti tebu yang dapat diolah menjadi bahan bakar (Walter V, Mariam K, \& Christopher B, 2020).

\section{Biogas}

Biogas merupakan energi alternatif dari energi batu bara dan fosil, biogas dihasilkan dari proses yang berlangsung dalam bilik anaerob atau tanpa oksigen, bilik ini tidak menimbulkan bau karena tidak dapat menyebar. bahan baku untuk membuat biogas berasal dari substrat bahan organik, bahan baku yang dapat digunakan untuk pembuatan biogas merupakan limbah sisa aktivitas manusia, seperti limbah peternakan, limbah pertanian, limbah industri, limbah perairan, hingga sampah organik. Biogas dapat digunakan sama seperti penggunaan gas alam. Pemanfaatannya seperti distribusi melalui jaringan gas, pembangkit listrik, pemanas ruangan, dan pemanas air. (Fachverband Biogas e.V., 2019) 




Gambar 1. Skema Biogas

Sumber: Medanternak.com, 2021

\section{Biokatoda}

Teknologi biokatoda menjadi sumber energi terbarukan yang dapat memperbaharui tidak hanya berkelanjutan, biokatoda menghasilkan listrik sementara tanaman terus tumbuh, para peneliti mengatakan bahwa sistem pertumbuhan tanaman tidak merusak lingkungannya. Teknologi ini bekerja dengan memanfaatkan hingga $70 \%$ bahan organik hasil fotosintesis yang tidak dapat digunakan lagi oleh tanaman dan dikeluarkan melalui akar. Saat elektron dilepaskan sebagai produk limbah, alat elektroda di dekat bakteri untuk menyerap elektron ini sehingga dapat menjadi energi listrik. Plantmicrobial fuel cell dapat menghasilkan listrik sebanyak 3,2 W per meter persegi, yang memungkinkan atap seluas $100 \mathrm{~m} 2$ untuk memasok listrik ke rumah dengan konsumsi rata-rata $2.800 \mathrm{kWh}$ per tahun. Teknologi ini bekerja dengan berbagai jenis tanaman termasuk rumput (Gowtham \& Sundar, 2015).

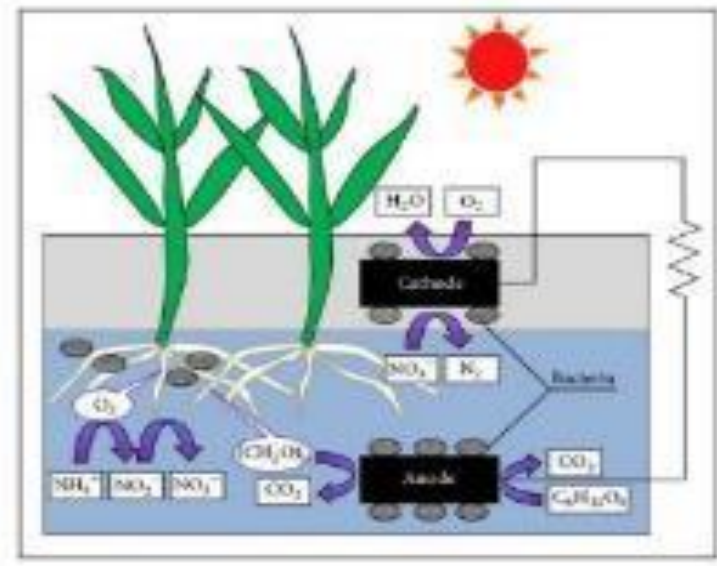

Gambar 2. Skema Biokatoda

\section{METODE}

Sumber: Hindawi.com, 2013

\section{Metode Penelitian}

Metode penelitian yang digunakan adalah metode kualitatif. Data yang digunakan berasal dari buku dan jurnal. Metode ini digunakan untuk memahami fenomena, isu dan permasalahan dalam konteks lingkungan, sehingga sebagian besar data bersifat naratif berdasarkan observasi holistik dari kejadian-kejadian yang terdapat pada konteks tapak beserta lingkungannya. Penelitian kualitatif digunakan untuk memperhatikan menentukan dan memahami aspek objektif, kebutuhan dan hal-hal lain yang diperlukan untuk memahami pembangunan yang lebih hijau.

Dengan menelaah informasi dan data yang telah dikumpulkan dari studi kasus maupun observasi langsung. Isu yang diangkat dan program arsitektur dapat terbentuk. 


\section{Metode Perancangan}

Metode perancangan yang digunakan adalah metode narasi arsitektur. Data kualitatif dianalisis dan diimplementasikan hanya sesuai dengan nilai narasi yang diangkat, sehingga ada unsur subjektivitas karena tidak semua data observasi digunakan yaitu narasi ecocriticism, merupakan sudut pandang filosofis dan konseptual penyelidikan wacana isu ekologi dalam konteks teori arsitektur yang lebih luas. Dalam perancangan, sebuah narasi dikembangkan sebagai ide awal untuk menciptakan bentuk keruangan dan hubungan antar ruang. Kedua adalah narasi berfungsi sebagai alat untuk menginterpretasikan nilai-nilai ekologis dalam ide keruangan dan tatakan fungsi sehingga perancangan dapat mengubah paradigma manusia mengenai konsep ekologi yang mutualisme. Untuk mempermudah perancangan digunakan parameter ecosophy agar perancangan tetap dalam cangkupan pembahasan mengenai melampaui ekologi.

\section{DISKUSI DAN HASIL}

\section{Pemilihan Tapak}

Jakarta merupakan ibukota dari Indonesia yang memiliki kepadatan penduduk $16.704 \mathrm{jiwa} / \mathrm{km} 2$, yang menjadikan Jakarta menjadi sebuah kota metropolitan yang banyak menciptakan ketidakseimbangan ekologis secara nasional. Terutama pada bentuk segitiga imajiner yang terletak di tengah Jakarta yaitu Jakarta's Golden Triangle. Sebagian besar aktivitas bisnis, keuangan, dan diplomatik terjadi di garis imajiner ini, sehingga secara narasi penulis mendefinisikan segitiga imajiner ini sebagai pusat dari aktivitas antroposentris.

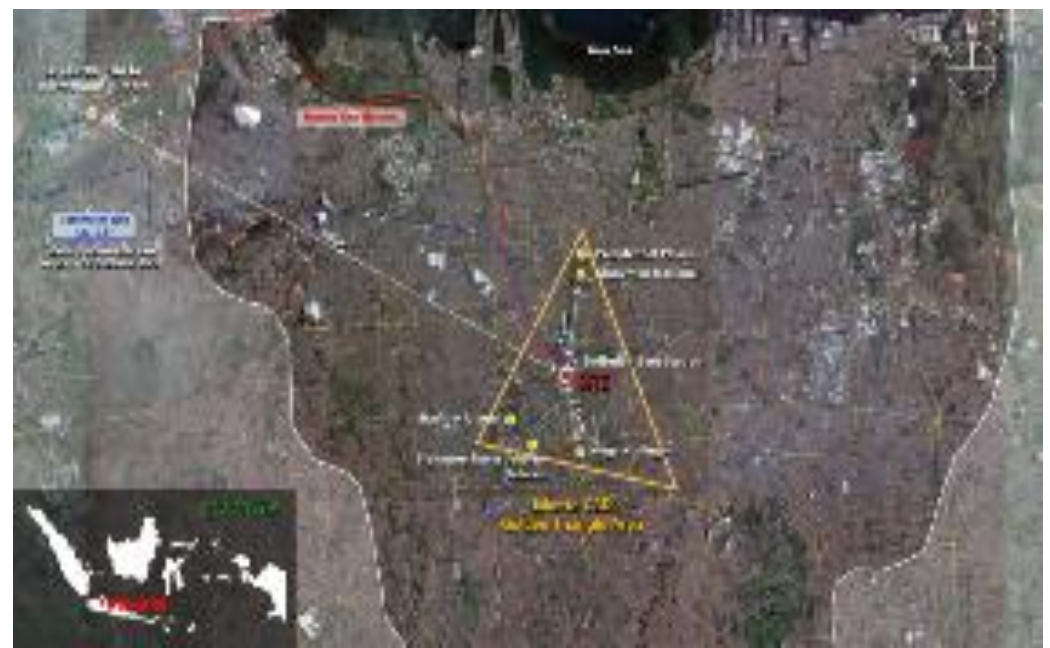

Gambar 3. Garis Jakarta's Golden Triangle Sumber: Medium.com, 2021

Sudirman Central Business District (SCBD) merupakan kawasan yang sangat padat dari salah satu dari sekian banyak kawasan bisnis di Jakarta, dan merupakan yang paling padat diantara kawasan bisnis lainnya yang ada di Jakarta's Golden Triangle. Tapak terpilih berada di Jl. Jendral Sudirman, SCBD, Jakarta Selatan, terletak diantara kawasan District 8 dan gedung kantor Pacific Century Place. Hal yang dijadikan modal awal dalam pemilihan tapak adalah data kepadatan penduduk, zona peruntukan perkantoran, dan tingkat kemakmuran angkatan kerja dan berlokasinya berada didalam segitiga imajiner Jakarta's Golden Triangle. 

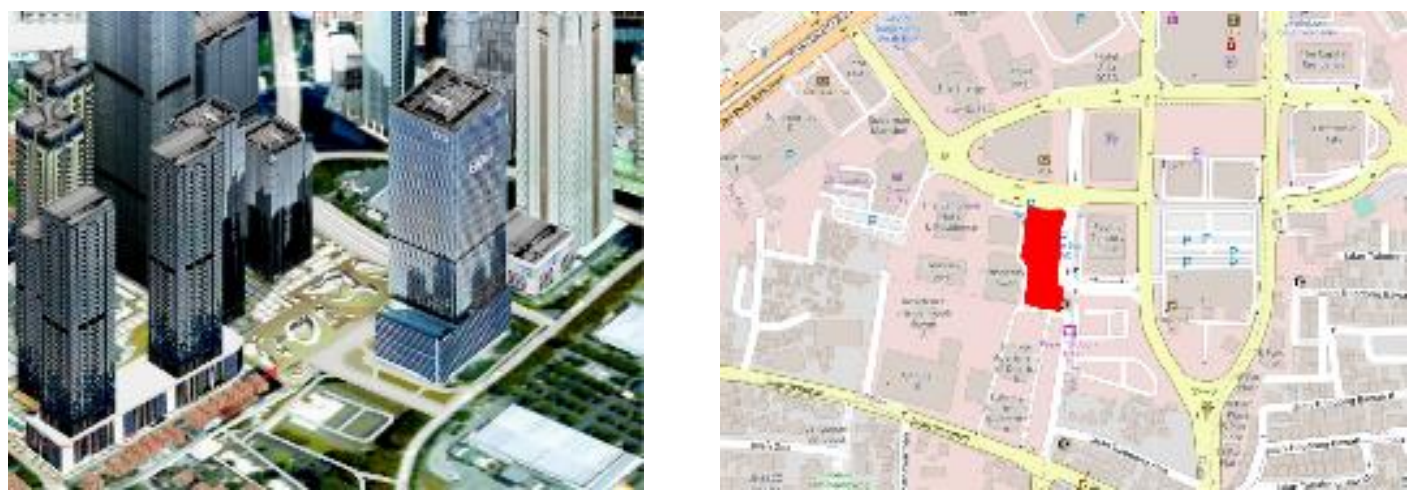

Gambar 4. Lokasi Tapak di SCBD

Sumber: Penulis, 2021

\section{Analisis Tapak}

Konteks Sekitar

Sekitar tapak dikelilingi oleh bangunan gedung pencakar langit, tepat sebelah timur dan selatan tapak merupakan gedung perkantoran, oleh karena itu kedua bangunan diangkat sebagai sasaran pengguna, dan bangunan yang berperan sebagai ruang perantara. 50 meter dari tapak terdapat parkiran umum kawasan, dapat dimanfaatkan sebagai parkiran pengunjung ke tapak, sehingga rencana luasan parkir dalam perancangan dapat dimanfaatkan sebagai area hijau.

\section{Aktivitas dan Sosial}

Pada hari kerja, aktivitas dipenuhi dengan kegiatan kantor, sekitar tapak menjadi area istirahat pada jam istirahat kantor. Pada ahkir pekan terdapat aktivitas olahraga dan keluarga di sekitar tapak dan area parkir umum. Sedangkan aktivitas selain manusia sekitar tapak terdapat beragam serangga kecil seperti belalang pelangi, angang-angang yang hinggap di bunga cendrawasih dan burung gereja dan merpati yang berterbangan hinggap di pohon trembesi.

\section{Analisis Program}

Dari data analisis, program yang dipilih akan memfasilitasi ekosistem dalam lingkup mikro. Segala isu yang kiranya dapat diselesaikan dalam rangka ecocriticism akan ditambah menjadi program baru agar proyek secara narasi menjadi ruang antitesis yang justru dapat menyadarkan manusia akan dampak buruknya dominasi manusia terhadap ekosfer dan menjalin kembali intedependsi manusia dengan makhluk hidup lainnya.

\section{Habitat Keanekaragaman Hayati}

Lahan hijau di kawasan pusat bisnis hanya sebesar $12 \%$, tapak merupakan salah satu ruang hijau terbesar di kawasan pusat bisnis SCBD. Ruang hijau dapat dimanfaatkan tidak sebagai vegetasi saja, melainkan ruang tinggal bagi seluruh makhluk. Program habitat keanekaragaman hayati hadir sebagai habitat seluruh makhluk yang mengevaluasi pemanfaatan ruang terbuka hijau dalam sebuah kawasan dan mengembalikan tapak sebagai rumah bagi keanekaragaman makhluk hidup dalam ekosistemnya.

\section{Pusat Jajanan}

Secara kontekstual, pusat jajanan dihadirkan untuk menaungi kebutuhan dan aktivitas manusianya, dengan merespon masalah yang ada dalam skala lingkungan seperti:

- Menjadi ruang pelepas stress bagi pekerja kantoran setempat.

- Merancang ruang istirahat yang layak pada saat jam makan siang.

- Menaungi pujasera yang akan digusur tepat disebelah tapak dan kawasan District 8.

- Menyediakan ruang untuk aktivitas olahraga dan keluarga pada ahkir pekan. 
Sehingga pusat jajanan ini bukan hanya menjadi tempat makan saja, tetapi memiliki makna lebih sebagai ruang istirahat, ruang ketiga dan ruang yang menciptakan kesadaran akan ekologi dengan terintegrasinya dengan program habitat keanekaragaman hayati.

\section{Pembangkit Listrik Tenaga Bioenergi}

Menjadi irisan dari program habitat keanekaragaman hayati dan pusat jajanan, keduanya menghasilkan sebuah energi yang dapat diolah berulang-ulang hingga menjadi bioenergi yang membangkitkan listrik bangunan dan sekitarnya. Sehingga dengan teknologi bioenergi, memanfaatkan alam dan organik bukan hanya sustainable (berkelanjutan) tetapi regenerative (memperbaharui), dimana makin bertumbuh faktor hijau makin banyak juga energi yang dihasilkan.
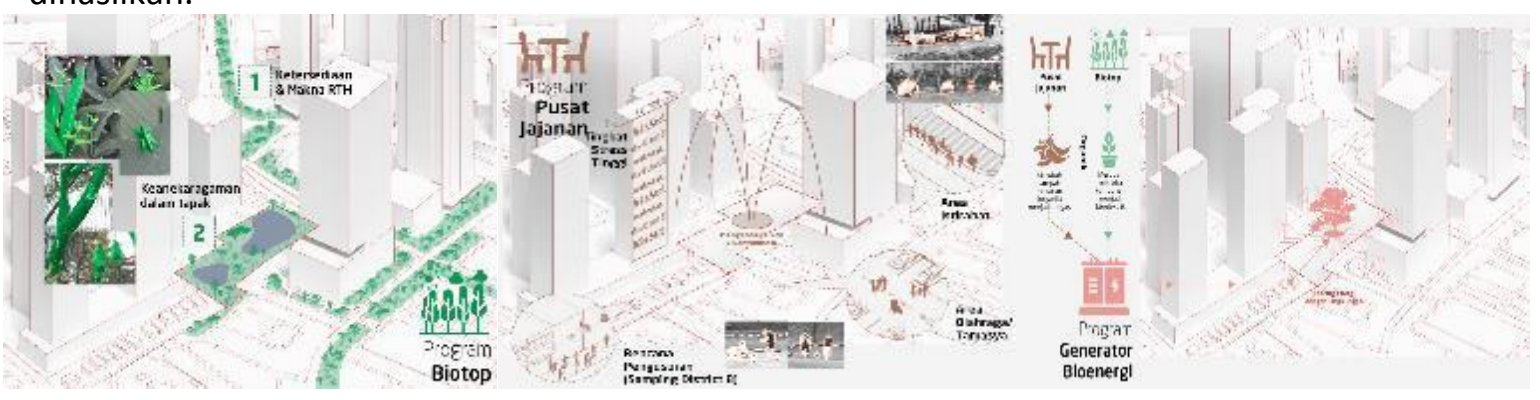

Gambar 5. Illustrasi Program Habitat Keanekaragaman Hayati, Pusat Jajanan dan

Pembangkit Listrik Tenaga Bioenergi

Sumber: Penulis, 2021

\section{Skema Desain}

Skema desain dimulai dari pendataan dan peletakan untuk program selain manusianya, banyak konfigurasi dan pembentukan massa terkait aktivitas dan kebutuhan ruang hewan dan tumbuhannya dibandingkan aktivitas manusia, sehingga proyek memiliki bangunan dengan proporsi yang seimbang antara manusia dan selain manusia dalam pembentukan massanya.

\section{Skema Bioenergi}

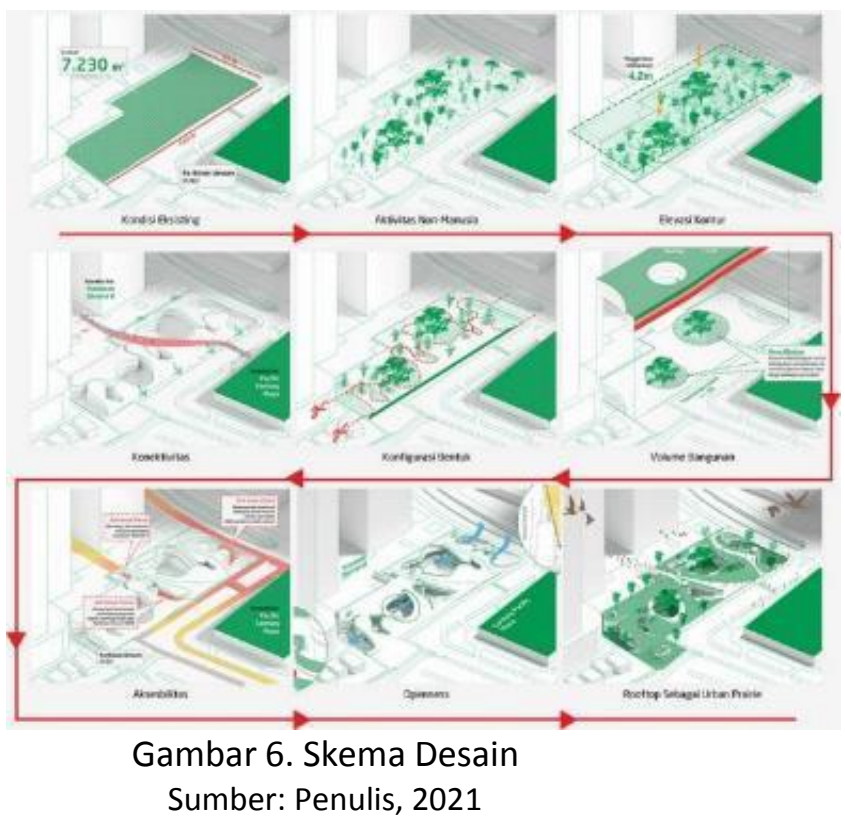

Berikut skema untuk program generator bioenergi dan alurnya pada bangunan, seluruh sampah dari area makanan dikumpulkan melalui kios dan diturunkan melalui shaft dapur basah, sedangkan limbah kotoran melalui shaft yang ada di toilet. baru keduanya diproses dimasukan 
ke bilik pencernaan anaerobik biogas yang berada di basement 2 hingga diolah menjadi bioenergi. Untuk program habitat keanekaragaman hayati, di area yang terdapat pohon dan lumut, lapisan tanahnya dipasang lapisan fiber karbon sebagai katode dan anode. sehingga elektron sisa dari proses fotosintesis dapat tertangkap dan diubah menjadi bioenergi, lalu bioenergi disalurkan dan disimpan di area kontrol pusat yang terdapat akumulator dan generator untuk disalurkan menjadi pelistrikan bangunan.

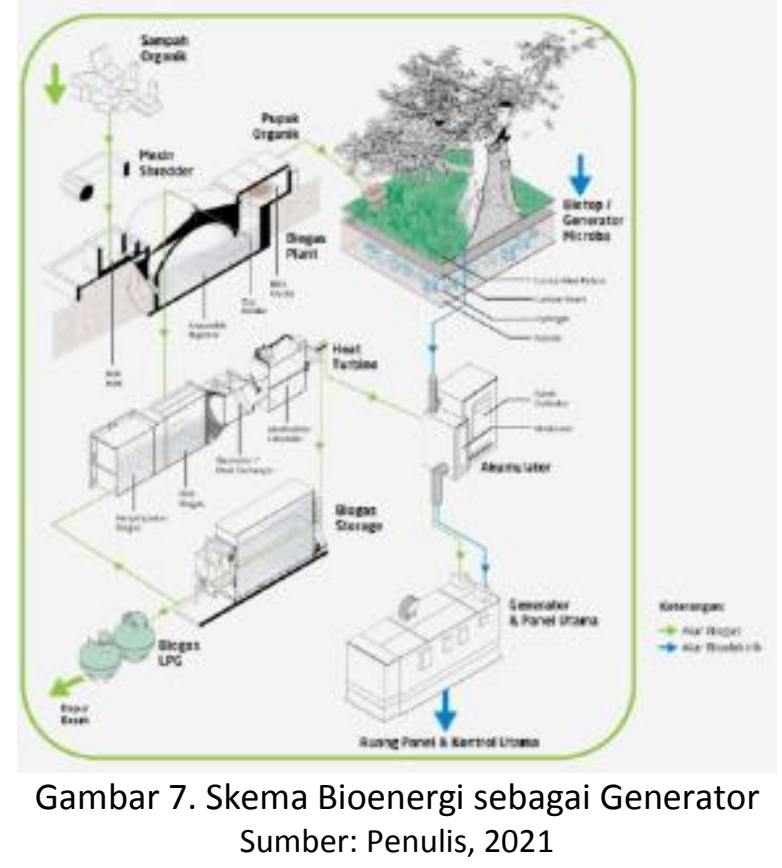

\section{KESIMPULAN DAN SARAN Kesimpulan}

Habitat keanekaragaman hayati dan pusat jajanan dapat digabungkan menjadi sebuah program yang saling interdependensi yang menghasilkan keharmonisan dan energi yang memperbaharui lingkungannya melalui generator bioenergi. Perancangan bangunan dibangun berdasarkan parameter ecosophy sehingga bangunan tetap sesuai dengan tema rancangan ekologis yang lebih hijau. Bangunan ini memperhatikan persamaan hak antar makhluk hidup dengan menonjolkan perbandingan koefisiensi dasar bangunan sebesar $60 \%$ untuk manusia dengan koefisiensi daerah hijau sebesar $40 \%$ untuk ruang makhluk hidup selain manusia, dan juga memulai perancangan dengan mengutamakan aktivitas dan kebutuhan hewan dan tumbuhan sebelum memasukkan program manusianya kedalam bangunan. Konsep keterbukaan mempertimbangkan kualitas hidup hewan maupun tumbuhan dan interaksinya dengan manusia. Program habitat keanekaragaman hayati bukan hanya melestarikan lingkungan tetapi memperbaharui keanekaragaman hayati, sehingga merubah persepsi ruang terbuka hijau dan vegetasi dalam sebuah bangunan menjadi sebuah ruang interaksi antar makhluk dan menjadi hidup.

\section{Saran}

Jakarta merupakan ibukota Indonesia yang memiliki pengembangan infrastruktur dan pembangunan kawasan yang diutamakan, pembangunan kawasan harusnya memperhatikan ruang terbuka hijau sebagai ruang-ruang perantara yang mewadahi ekosistem sekitarnya agar tetap harmonis hubungan antar makhluk hidup dalam sebuah kawasan. 


\section{REFERENSI}

Alaimo, S. (2010). Bodily Natures: Science, Environtment, and The Material Self. Bloomington, Indiana: Indiana University Press.

Bar, H. (2020). COVID-19 Lockdown: Animal Life, Ecosystem and Atmospheric Environtment. Springer Nature.

Bilqis, N. (2020). Analisis Dampak Kasus Kebakaran Hutan di Indonesia Terhadap Hubungan Diplomatik Indonesia dengan Malaysia dan Singapura. Gorontalo Journal of Goverment and Political Studies.

Bratton, B. H. (2015). The Stack: On Software and Sovereignity. Massachusetts: The MIT Press.

Broadbent, S., \& Lobet-Maris, C. (2015). Towards a Grey Ecology. Dalam L. Floridi, The Online Manifesto: Being Human in a Hyperconnected Era (hal. 111-124). New York City: Springer Publishing.

Cohen, J. J. (2013). Prismatic Ecology: Ecotheory Beyond Green. Minneapolis: University of Minnesota Press.

Cook, C. (2019). Regenerative Architecture as a pathway beyond sustainability . Diambil kembali dari issuu.com:

https://issuu.com/catherineronniecook/docs/regenerative_architecture_as_a_pathwa y_beyond_sust

Devall, B. (1985). Deep Ecology. Layton, Utah: Gibbs M. Smith, Inc.

Fachverband Biogas e.V. (2019). Biowaste to Biogas. Angerbrunnenstraße: Fachverband Biogas e.V.

Gowtham, R., \& Sundar, K. (2015). Generating Current From Plants Plant-e Technology.

Haenlein, A. F. (2016). The emergence and evolution of trans-corporeality in Charles Darwin's On The Origin of Species and. Graduate Theses and Dissertations. 15027.

Mazzoleni, I. (2013). Architecture Follows Nature: Biomimetic Principles for Innovative Design. CRC Press.

McDonough, W., \& Braungart, M. (2002). Cradle to Cradle: Remaking The Way We Make Things. New York: North Point Press.

Naboni, E., \& Havinga, L. (2019). Regenerative Design in Digital Practice: A Handbook for the Built Environtment. Bolzano: IT:Eurac.

Walter V, R., Mariam K, A., \& Christopher B, F. (2020, January). The Future of Bioenergy. Glob Chang Biol, 274-286. doi:10.1111/gcb.14883

Young, L. (2019). Neo-Machine: Architecture Without People. Dalam L. Young, Machine Landscapes: Architectures of The Post-Anthropocene (hal. 6-10). Oxford: John Wiley \& Sons Ltd. 